\title{
EFFECT OF NON-AUDIT SERVICES ON AUDITOR'S INDEPENDENCE: EVIDENCE FROM ACCOUNTING PRACTITIONERS IN ABIA STATE
}

\author{
Ogbodo, Okenwa Cy \\ Department of Accountancy \\ Nnamdi Azikwe University, Awka \\ Mail: cyogbodo2016@yahoo.com \\ Ajuonu, Anurika \\ Department of Accountancy \\ Nnamdi Azikiwe University, Awka \\ Mail: anulikings@yahoo.com
}

\begin{abstract}
This study investigates the effect of the provision on non-audit services on Auditor's independence: evidence from accounting practitioners and consequent effect on the auditor's objectivity and professional skepticism in the financial statement audited. The study used the Institute of Chartered Accountants of Nigeria (ICAN) and Association of National Accountants of Nigeria (ANAN) domiciled in Abia State. The data for the study were generated from primary source: questionnaires were the major instrument for data collection. The instrument was subject to both content and faces validity by experts. Three questions were structured in Likert scale form and the formulated hypotheses were tested with ordinary Logistic regression using SPSS package. The study found that non-audit services have no effect on auditor's independence, the auditor's objectivity and professional skepticism. The study therefore recommends that the audit committee should have full oversight of the auditor's independence, including the nature and extent of the work they do and their fees. The audit committee should make its charter public. The charter should give investor information about how the audit committee chooses its auditors and how it decides the type of service they can provide.
\end{abstract}

Keywords: Non-audit services, Auditor's independence, Auditor's objectivity, and Professional skepticism. 


\section{Introduction}

The impact of non-audit service on auditors independence has been a debate for years now, it has posed a question on the independence of the auditors, and the recent report in questionable accounting practice employed by some companies in Nigeria have brought the issue of auditor independence to the fore front and putting the auditing profession in a serious credibility crisis (Olusanya \& Lauwo 2010). Non-Audit service (NAS) is a much discussed topic in the world today. Some recent issues have triggered it much more because the conflict of interest people believed that how can an auditor question the value of the appraised assets in the client financial statement in which he was part of its formulation. In Nigeria the collapse of banks, companies, like in the recent times like the Cadbury Nig Plc accounting scandal which came to the fore in 2006 (SEC 2006). This scandal which has since been liken to the Nigeria's Enron equivalent in terms of its magnitude drew the attention of the Nigeria Security and Exchange Commission (SEC) on the auditors of the company, the auditors were accused among other things of failure to exercise due diligence and lack of professional skepticism in carrying out the audit of the company. This provision of non-audit service and auditors independence is of the three views; some are of the views that it leads to knowledge spillovers, hence the auditors have mastered the company while some are of the view that it leads to the economic bonding between the client and in the long run it affects the auditors independence and beclouds the judgement on the true position of the company. Some are of the view that it does not affect the auditors independence and professional skepticism.

An observation of statutory pronouncement like section 357 or the Nigerian Companies and Allied Matters Act (CAMA) 1990, as amended, requires companies to have their financial statement audited by an independent auditor for any financial year. It can be perceived that managers are responsible for the preparation of annual account, designing and implementing internal controls and advice all ensuring the smooth running of the business. CAMA (1990) section 358(2c) disqualifies a person or firms who or which offers to the company professional advice in a consultancy capacity in respect of secretarial, tax action or financial management from acting as auditor of that same company. This ensures that an auditor is independent (in appearance) of the organization on whose accounts he reports. But in Nigeria where the problem lies is Nigeria auditors accepting all services, Anichebe (2010) observes that in Nigeria auditors accept all services (except those for which the auditor has no expertise) as long as there are engagement letters, he argued that the existing independence rules are clearly breached.

The unpleasant audit failures in Nigeria and elsewhere around the world have prompted the search for effective way to enhancing the Audit quality, Professional Skepiticism, Auditors Independence, Behaviour and Competence on side of the external auditors when carrying out non-audit service like Corporate Governance, Advisory service; Valuation, Recruitment, Financial Accounting Information and so on. The challenge is that corporate management hires, fires and pays both internal and external auditor. Auditors therefore often develop harmonious relationship with the management to retain the job of the client (Adeyemi \& Okpala, 2011).

These audit failures that have been reported led to major criticism of the auditing profession worldwide by exposing the weakness of the profession in terms of safeguarding shareholders and stockholders interest (Brandon et al 2004, Citron 2003, Cullinane 2004, Fearnley and Beattie 2004). 
Stakeholders believed that the heart of audit failure lies on issue of Auditors independence, Objectivity and Professional Skepticism. Many factors may make an Auditor to bend some rules most especially during provision of non-audit services by auditors of the same firm. It is in the light of this that gives rise to the study on the effect of non-audit services on Auditors Independence, Professional Skepticism and Objectivity: evidence from Accounting Practitioners in Abia State.

This study was conducted to establish how auditors have fared given the contending issue of the effect of non-audit service on auditors independence with special regard to the accounting practitioners in Abia State. And this study will uncover the real condition of non audit service and the perception of financial accounting prepares Accountants about this issue to ensure that the financial statements prepared are not affected by conflict of interest. It is against this background that this research attempts to examine the effect of non-audit service on Auditors Independence, Professional Skepticism and Objectivity using the data from Abia state Nigeria.

The main objective of this study is to empirically examine the effect of non audit service on auditor's independence: evidence from accounting practitioners in Abia State, South East Nigeria.

The specific objectives

1. To determine the effect of financial accounting information system services on auditor's professional integrity and objectivity in South East Nigeria.

2. To determine the effect of valuation services on auditor's professional competence, skepticism and behaviour in the South East Nigeria.

3. To examine the effect of management advisory and corporate governance services on auditors' conformity with technical standard and professional judgment in South East Nigeria.

\section{Research Hypotheses}

The following null hypotheses will be tested at $5 \%$ level of significance:

1. The effect of financial accounting information system services on auditor's professional integrity and objectivity in South East Nigeria is not significant.

2. The effect of valuation services on auditor's professional competence, skepticism and behaviour in the South East Nigeria is not statistically significant.

3. The effect of management advisory and corporate governance services on auditors' conformity with technical standard and professional judgment in South East Nigeria is not significant.

\section{Conceptual Framework}

\section{Auditors Independence}

Audit independence refers to the ability of the external auditor to act with integrity and impartiality during his/her auditing function.

Independence is an abstract concept and it is difficult to define (Schuette, 1994). Nevertheless, in defining auditor independence the literature selects objectivity, the ability to avoid biases; and integrity, willingness to report a truthful opinion that reflects the matter 
discovered during the audit. (De Angelo 1981).

According to (Ekezie, 2008), the fundamental concept of professional independence is an attitude of mind based on integrity and objective approach to work. He maintained that an auditor must at all times, perform his research objectively and impartially and free from influence by any consideration which might appear to be in conflict with this requirement. It is where the auditor should not be under the influence of client at any given circumstances. In a similar vein, The Independence Standard Board cited in Salehi (2009) defines independence as freedom from pressures and other factors that impair or are perceived to impair, an auditor's willingness to exercise objectivity and integrity when performing an audit.

It is the absence of certain activities and relationship that may impair or may perceive to impair an auditor's willingness to exercise objectivity and integrity when performing an audit. (Ekezie 2008) argue that professional independence may either be corporate independence or individual independence. Corporate independence means independence of professional accounting body as a whole whereas individual independence is that of the member of an accounting profession in the research place.

Auditor independence is defined as probability that the auditor report a discovered breach in financial statement reports (Watts and Zimmerman, 1983).

Independence may be in a state of mind or behavior, this requires the auditor to be free from bias, personal interest, prior commitment to an interest or susceptible to undue influence. This means that an average auditor possessing the requisite state of mind will act in the correct way that will not affect the professional duty of due care and skill. Also Appah (2008) note that independence in auditing means having a position to take an unbiased view point in the performance of audit test, analysis of results and attestation in the audit report.

The IFA (2003) Code states that the state of mind that permits the provision of an opinion without being affected by influences that impair professional judgement, allowing an individual to act with integrity and exercise objectivity and professional skepticism.

Independence is one of the key factors of an auditor and without it the user of the financial statement cannot rely on the auditor's report. The concept of audit independence is fuzzy, the rules governing it are complex and burdensome and a reexamination is long overdue (Elliott and Jacabson, 1992). De Angelo (1981) defined auditors independence as "the conditions probability of reporting a discovered breach.

\section{Factors Affecting Auditor's Independence}

Several situation may impair the auditor's independence such as contingent fee arrangements, gifts, auditors with personnel or operations, Non-audit - services (NAS) out sourcing, opinion shopping, reporting relationship.

Opinion shopping:-It is an unlawful action of seeking auditors that are willing to cast the company accounting procedures in a positive light despite the reality of the situation.

Outsourcing: is an arrangement in which one company provides services for another company that could also be or usually have been provided in house. 
Reporting Relationship: this is how a company holds accountability and rewards employees based upon professional actions.

\section{Threats to Auditors Independence}

Self Review Threat:-This is a type of threat that has to do with the inability of the auditor to identify and accept weakness and mistakes in a previous audit (Okezie 2008).

Self-review threat is a situation in which the auditor finds it difficult to evaluate without bias of one's own work E.g. an auditor assisting an audit in preparing accounting records or a member of audit team was previously a director. According to Eilifsen (2006 P.500), selfinterest arises from the auditors favoring their self-interest over their interest in performing an unbiased audit, (e.g.) Auditor's family relationship with management of an auditor.

Advocacy threat:- it is a threat where the auditor takes an advocate for or against the clients position in any situation.

Familiarity threat arises in situations where the auditor compromised objectively because they are influenced by a close relationship with the audit client.

\section{Non Audit Services}

Non audit services is defined by the financial reporting council (FRC) as any engagement in which an audit firm provides professional services to an audited entity, its affiliates or another entity in respect of the audited entity other than the audit of the financial statement $\operatorname{FRC}(2010$ p.6).

Non-audit services may be referred to in the Professional and academic press as management advisory services or consulting but non audit service includes compliance related services such as taxation and accounting audit and assurance related service such as due diligence and closely linked to the annual financial reporting round (Beattie Brandt and Fearnley (1996)

Non audit is used to describe services that an accountant provides for a company such as giving advice that does not involve checking the company financial records (Cambridge Business English Dictionary). According to 15 USCS \& 720I (8), the term non-audit service means any professional services provided a registered public accounting firm other than those provided to an issuer in connection with an audit or a review of the financial statement of an issuer.

According to cornel law school, non audit services are any professional services provided by a qualified public accountant during the period of an audit engagement which are not connected to an audit or review of an institution's financial statement. Non -audit service is defined by the financial reporting council (FRC) as any engagement in which an audit firm provides professional service to an audited entity, its affiliates or another entity in respect of the audited entity other than the audit of financial statement FRC(2010 p.6).

i. An auditor cannot function in the role of management

ii. An auditor cannot audit its own work

iii. An auditor cannot serve in an advocacy role for its client

In Nigeria, the two non audit services provided by auditors are tax advice and management consultancy. The range of services now offered by the audit firm to both the public and private sector is wide. This may be summarized as follows:- 
a) System and Training, Services for payroll, Risk management advice, Risk management advice, Taxation, including tax compliance and tax planning advice, Corporate recovery and insolvency, Forensic and litigation support, Mergers and acquisitions services, Transaction support and follow up, Public offering, Recruitment and human resource and Portfolio monitoring

\section{Management Advisory Service (MAS)}

Management advisory service as cited in (Salehi 2009) which consists of advice and assistance to a client to improve capabilities and resources and achieve stated objectives. The accountant may conduct studies and counsel management in such matters as business organization, planning, controls, system's operation, personnel and finances. Management engagements require an investigation and analysis of the client's operations to determine the enterprise's objectives, the nature of the problem, and feasible solutions. They also include the evaluation of alternative solutions, formulation and recommended action, and suggestions for assistance in the implementation process. MAS could also require the review of the financial statements for a client. All these professional services may pose a threat to the auditor's independence. Auditors must, therefore, exercise due care to preserve their status of independence.

In providing management advisory services including training programs, supervision, review of engagements and co-contracting those in charge should emphasize the significance of independence in mental attitude (Cook et al, 1988).

\section{Professional Skepticism}

A concept of Auditor Professional Skepticism is an important concept in audit practice and an intrinsic part of the audit process.

The word skepticism is formed from the root "skeptic" which comes from the Greek word "skeptikos" meaning "inquiring or reflective." To inquire is to seek information by questioning to ask. The characteristics commonly associated with being a skeptic include questioning and careful observation, probing reflection, looking beyond the obvious, and suspension of belief.

The International Standard on Auditing (ISA) 2000 defines Auditor Professional Skepticism as "an attitude that includes a questioning mind, being alert to conditions which may indicate possible misstatement due to error or fraud and a critical assessment of audit evidence". They explicitly require the auditor to plan and perform an audit with professional skepticism recognizing that circumstances may exist that cause the financial statements to be materially misstated. As noted by the international Auditing and Assurance Standards Board (IAASB), professional skepticism is therefore rather found within the mental processes of an audit team.

The application paragraphs of ISA 200 contain more guidance on what is meant by professional skepticism when conducting an audit.

Essentially, ISA 200 requires the use of professional skepticism as a means of enhancing the auditor's ability to identify risks of material misstatement and to resound to the risk identified. Professional Skepticism is closely related to fundamental ethical considerations of auditor objectivity and independence. Professional Skepticism is also linked to the 
application of professional judgment by the auditor.

\section{Theoretical Framework \\ Agency Theory}

This work is anchored on agency theory; it is the theory that underpins this study. This theory is more often used in research context; it incorporates part of policeman and lending credibility theory. It explains the demand for audit, it is about the agent and the principal of a company, whereby the agent is the management and the principal is the owner. The principal provides the finance but lack the expertise knowledge to manage the business and therefore, hires the manager who has the expertise knowledge to run the day to day activities of the business.

There is always a problem between these two known as the agency problem which may occur when the principal (investors) do not intend to play an active role in the management of the company and also when the manager have the incentives to maximize its own interest instead of maximizing the wealth of the shareholders (Jensen \& Meckling, 1976; Chow, 1982). When an investment in a company is made by an external investor, managers have theoretically an incentive to expropriate wealth thereby creating an agency problem (Healy \& Palepu, 2001). Agency conflict can also be applicable on the management-creditor relationship. Management will expropriate wealth from the creditors to maximize the wealth of the shareholders (Eilifsen et al (2010), Collins et al. (2004).

According to the Agency theory, the essence of Audit service can bring about the maximum benefit to both the Agent and the Principals (Ross, 1973). This audit will lead to;

i. A cost-effective monitoring device.

ii. Reduces information asymmetries by adding credibility to financial statements

iii. Has an important role in a setting were ownership and management of the firm is separated and in the relationship between mangers and creditors.

iv. Reduces risk for investors. Auditing gives a positive signal effect.

As a matter of facts, the agent has a greater advantage over the principals (shareholders) regarding company's information, This theory can also be used to explain the independence of auditors based on their audit reports to third parties. If an auditor is able to identify material misstatement or other irregularities such as violation of the accounting standard (illegal acts) or fraud in the financial statements of the company and willing to report this to qualify its audit reports against the wish of the audit client, therefore the auditor has maintained its independence in this conflict between the auditor (principal) and the audit client (agent)

\section{Empirical Review}

Relevant studies had been carried out on non audit service and auditors independence with most studies having mixed results.

Akhalumeh Ireghan \& Mohammed (2015) studied the provision of non audit services and auditor's independence on Nigeria auditors in the banking industry and found out that provision of non audit service affects auditor independence and quality of financial statement. Dr. Awa Felix (2015) in his study on auditor's independence and the provision of non audit service investors perceptive in Nigeria found out that non audit service significantly affect 
investors perception of auditors independence and that there is a high correlation between auditors independence and non-audit services in Nigeria.

Babatolu ,Aigienohuwas \& Uniamikogbo. (2011), The study revealed that there is a positive relationship between audit fee and audit firm relationship between audit tenure and audit quality the correlation is strong and negative and statistically significant.

Semiu \& Kehinde (2011) studied stakeholders perception of the independence of statutory auditors in Nigeria, and observed that respondents perceived size of audit fee as the most influencing factor capable of determining Auditor Independence. Semiu, Okwu \& Eyesan (2012) studied factors affecting audit quality and independence in Nigeria, and found out that provision of non-audit service would likely have a significant effect on audit quality likewise auditors independence in Nigeria.

Uchenna (2008) studied determinants of auditor independence; a comparison of the perception of auditors and non-auditors in Lagos Nigeria. It found out that there are some services that impairs auditors independence between the two groups and that were differences in the degree to which they affect auditor independence. Ogbomo, Innocent \& Enofe (2015) studied the effect of accounting ethics in improving Auditor Professional Skepticism. The study findings show the existence of positive and significant relationship between Accounting Ethics and Auditors Professional Skepticism. In addition Auditor Tenure and Audit fee were found to have a negative significant relationship with Professional Skepticism. Okaro, Okafor \& Egbunike (2013) studied Mandatory rotation of Auditors; the Nigerian Accountants perception. The questionnaire findings, suggest that four factors ranked high in the respondents desire to see mandatory rotation of auditors enthroned in Nigeria. They are that it will enhance the independence of the Auditor, give opportunity for periodic fresh look into an institution by another Auditor, help the Auditor maintain his Professional skepticism and enhance the ethical behavior of Auditors. Okaro \& Okafor. (2014) studied joint provision of audit and non audit service in Nigeria; an empirical study. The findings suggest that professional accountants are of the opinion that provision of non audit service to audit client impair the independence of the auditor. Beyond that, however, they prefer selective prohibition by NAS to audit client on the basis of the nature of work. One of the Big 4 auditing firm operating in Nigeria disagrees with the view that allowing auditors to carry out any non-audit service for their audit Client weakness their Independence Objectivity and Professional Skepticism, they believe that certain activities are without doubt in conflict with independence of the audit and should be prohibited. That for all other services the audit committee is in the best position to take decision on whether they are consistent with company own governance in relation to the quality price and efficiency of non-audit service proposed (Price water house coopers, 2015). Holland \&lane (2012) however reject prohibition of auditor from providing no auditing service to its audit clients. Bell, Caushoili and Knechel (2012) did not find the provision of non audit services compromises audit quality. Olusanya \& Lauwo (2010) studied the role of auditors in the failure of Nigeria banking system and indicated Nigerian auditors with numerous instances of sloppy audit reporting this study further pointed out the quality of audits depends on technical skills of the audit teams and organizational values and labor processes embedded within the forms. AIAjmi \& Saudagaran (2011) carried out a study as audit firm size as factors affecting auditors independence and conclude that being a sole-practitioner and being a small, local audit firm impair auditors independence. 
Baker, Rahman \& Rashid (2005) argued that Audit firm is the most important factor affecting independence and that smaller Audit firms are more likely to lose independence. Ojo (2009) argued that the provision of non-audit service does not necessarily impair auditor independence especially when the fees from such service are less than the fees from audit service.

In relation to management advisory services (MAS). Gul \& Tsui (1991) conducted a survey, also using Australian companies, that provision of management advisory services affects the in formativeness of earnings. They found evidence that the explanatory power of earnings for returns is less for firms that provide M.A.S Frankel et al (2002) found empirically that levels of discretionary accruals are higher for firms whose auditors provided NAS than for firms whose auditors do not provide such services.

None of the existing studies as reflected in the review was carried out in Abia state as this study intend to bridge these perceived gaps by using data gotten from Aba and Umuahia and hence the study.

\section{Methodology}

This study adopted a descriptive survey design, the statements were adapted to suite the characteristics of Abia Environment to help the researcher to examine the effect of Non audit services on Auditor's independence evidence from Accounting practitioners in Abia state.

The population of the study is made up of the following groups of accountants: chartered accountants (i.e. members of the Institute of Chartered Accountants of Nigeria) and Association of National Accountants of Nigeria) domiciled (practicing) in Aba, Abia State and Post graduate Students in Accountancy. Consultations from the district societies gave figures of fifty-three (53) (active members) for ICAN and one hundred and twenty seven (127) ANAN members in Aba, Umuahia and three hundred (300) Post graduate students.

For easier collection of data for analysis a judgemental sampling method was used.

The sample size was arrived at using scientific sample method proposed by Walpole (1974), - as in Osisioma (2004) as

$$
\begin{aligned}
& \mathrm{n}= \\
& \mathrm{SS}=\frac{\mathrm{Z} 2 \times(\mathrm{p}) \times(1-\mathrm{p})}{\mathrm{C} 2} \quad \text { or } \quad S S=\frac{Z^{2} p(1-p)}{C^{2}}
\end{aligned}
$$

A Z-value (Cumulative Normal Probability Table) represents the probability that a sample will fall within a certain distribution.

The Z-values for confidence levels are: 
$1.645=90$ percent confidence level

$1.96=95$ percent confidence level

$2.576=99$ percent confidence level

Thus,

Ss $=$

$$
\underline{1.96^{2}}=\underline{2.576^{\sim}} 141.9 \sim 142 \text { questionnaires } 4(0.065)^{2}
$$

In order to reach out to relevant informed stakeholder's judgmental system of apportioning questionnaires to various strata of the sample population were adopted using a 15 -item Questionnaire.

The instrument was divided into two sections. Section A sought information regarding respondents biographic data while section B sought responses based on the purposes, research questions and hypothesis. A four (4) point rating scale and response was weighted for the instrument.

Table 1: Rating Scale Options

\begin{tabular}{ll}
\hline Options & Rating \\
\hline Strongly Agree (SA) & 4 \\
Agree (A) & 3 \\
Disagree (SD) & 2 \\
Strongly Disagree (SD) & 1 \\
\hline
\end{tabular}

The content and construct were ensured by giving the questionnaires to two independent assessors aside from the supervisor and professional accountant. The questions in the questionnaire were structured in line with the objective of the study.

A pilot study was conducted to determine the reliability co-efficient of the instrument using Cronbach alpha. To achieve this, the instrument was administered on twenty auditors. The instrument contained fifteen items divided into three sections, that is, B1, B2 and B3 with their respective Cronbach alpha estimates; .955, .970, .976 and the overall reliability estimates of .989 was obtained, see appendix-1 for more details. Therefore the instrument was considered appropriate for the study as it showed the measure of internal consistency of the data.

The primary data was collected through the issuance of questionnaire; one hundred and forty two questionnaires were distributed (142), one hundred and thirty two retrieved (132) were duly completed.

The data collected for the study was analyzed using non-parametric statistical technique, that is, ordinal logistic regression to analyze the research questions and test the research hypotheses.

\section{Decision rule}

The null hypotheses is rejected (and the alternative accepted) if our calculated p-value or sigvalue is less than the $5 \%$ level of significance. 
Journal DOI: www.doi.org/10.46654/RJMP

Article DOI: $\underline{\text { www.doi.org/10.46654/RJMP.1432 }}$

Data Presentation and Analysis

\section{Analysis of Research Questions}

i. To what extent is the effect of financial accounting information system services on auditor's independence, professional integrity and objectivity in Abia State, South East Nigeria?

Table 2: Parameter Estimates of Cumulative Odds Ordinal Logistic Regression effect of Financial Accounting Information System Services on Auditor's Independence Professional Integrity and Objectivity (Link function: Logit)

\begin{tabular}{|c|c|c|c|c|c|c|c|c|}
\hline \multicolumn{2}{|c|}{ Financial Information Services on } & \multirow[t]{3}{*}{ Estimate } & \multirow{3}{*}{$\begin{array}{c}\text { Std. } \\
\text { Error }\end{array}$} & \multirow[t]{3}{*}{ Wald } & \multirow[t]{3}{*}{ df } & \multirow[t]{3}{*}{ Sig. } & \multicolumn{2}{|c|}{ 95\% Confidence Interval } \\
\hline Auditor's & Independence & & & & & & Lower & Upper \\
\hline $\begin{array}{l}\text { Professional, } \\
\text { Objectivity. }\end{array}$ & Integrity and & & & & & & Bound & Bound \\
\hline \multirow[t]{3}{*}{ Threshold } & {$[\mathrm{FAPI}=1]$} & -1.170 & .287 & 16.625 & 1 & .000 & -1.732 & -.607 \\
\hline & {$[\mathrm{FAPI}=2]$} & .154 & .283 & .296 & 1 & .586 & -.400 & .708 \\
\hline & {$[\mathrm{FAPI}=3]$} & 1.360 & .287 & 22.417 & 1 & .000 & .797 & 1.923 \\
\hline \multirow[t]{6}{*}{ Location } & Age & .003 & .007 & .222 & 1 & .638 & -.010 & .017 \\
\hline & {$[$ yearexp $=1]$} & .047 & .175 & .074 & 1 & .786 & -.295 & .390 \\
\hline & Yearexp $=2$ & .152 & .164 & .861 & 1 & .353 & -.169 & .472 \\
\hline & [yearexp=3] & $0 \mathrm{a}$ & & . & 0 & & . & . \\
\hline & Association=1 & .142 & .135 & 1.098 & 1 & .295 & -.123 & .407 \\
\hline & [association $=2]$ & $0 \mathrm{a}$ & . & . & 0 & . & . & . \\
\hline
\end{tabular}

Source: Researcher's computation via SPSS version-23

ii. To what extent is the effect of Treasury Advisory Services on auditor's professional Competence, Skepticism and Behaviour in Abia State South East Nigeria?

Table 3: Parameter Estimates of Ordinal Logistic Regression Effect of Treasury Advisory Services on auditor's professional competence, skepticism and behavior.

\begin{tabular}{|c|c|c|c|c|c|c|c|c|}
\hline \multicolumn{2}{|c|}{$\begin{array}{l}\text { of Treasury Advisory } \\
\begin{array}{l}\text { Services on } \\
\text { professional }\end{array}\end{array}$} & \multirow[t]{2}{*}{ Estimate } & \multirow[t]{2}{*}{$\begin{array}{l}\text { Std. } \\
\text { Error }\end{array}$} & \multirow[t]{2}{*}{ Wald } & \multirow[t]{2}{*}{ df } & \multirow[t]{2}{*}{ Sig. } & \multicolumn{2}{|c|}{$\begin{array}{l}\text { 95\% Confidence } \\
\text { Interval }\end{array}$} \\
\hline $\begin{array}{l}\text { Competence, } \\
\text { Behaviour in } \\
\text { East Nigeria? }\end{array}$ & $\begin{array}{r}\text { Skepticism and } \\
\text { Abia State South }\end{array}$ & & & & & & $\begin{array}{l}\text { Lower } \\
\text { Bound }\end{array}$ & $\begin{array}{l}\text { Upper } \\
\text { Bound }\end{array}$ \\
\hline \multirow[t]{3}{*}{ Threshold } & {$[\mathrm{VAS}=1]$} & -1.459 & .289 & 25.499 & 1 & .000 & -2.025 & -.892 \\
\hline & {$[\mathrm{VAS}=2]$} & -.014 & .283 & .002 & 1 & .962 & -.568 & .541 \\
\hline & {$[\mathrm{VAS}=3]$} & 1.111 & .286 & 15.087 & 1 & .000 & .551 & 1.672 \\
\hline \multirow[t]{6}{*}{ Location } & Age & .002 & .007 & .052 & 1 & .820 & -.012 & .015 \\
\hline & [year exp=1] & -.134 & .175 & .590 & 1 & .442 & -.478 & .209 \\
\hline & [year exp=2] & .037 & .164 & .050 & 1 & .823 & -.284 & .357 \\
\hline & $\begin{array}{l}\text { [year } \\
\exp =3]\end{array}$ & $0^{\mathrm{a}}$ & 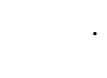 & & 0 & 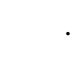 & . & . \\
\hline & [association=1] & -.041 & .135 & .094 & 1 & .760 & -.307 & .224 \\
\hline & [association $=2$ ] & $0^{\mathrm{a}}$ & . & & 0 & & . & \\
\hline
\end{tabular}

Source: Researcher's computation via SPSS version-23

iii. To what extent is the effect of Independent Assurance Work and Corporate Governance services on auditor's, Independence in Abia State South East Nigeria? 
Article DOI: www.doi.org/10.46654/RJMP.1432

Table 4: Parameter Estimates of Ordinal Logistic Regression Effect of Independent Assurance Work and corporate Governance services on auditors' independence in Abia State South East Nigeria.

\begin{tabular}{|c|c|c|c|c|c|c|c|c|}
\hline \multirow{2}{*}{\multicolumn{2}{|c|}{$\begin{array}{l}\text { Independent Assurance Work and } \\
\text { Corporate Governance Service and } \\
\text { Auditors' Independence in Abia } \\
\text { State South East Nigeria? }\end{array}$}} & \multirow[t]{2}{*}{ Estimate } & \multirow{2}{*}{$\begin{array}{c}\text { Std. } \\
\text { Error }\end{array}$} & \multirow[t]{2}{*}{ Wald } & \multirow[t]{2}{*}{ df } & \multirow[t]{2}{*}{ Sig. } & \multicolumn{2}{|c|}{$95 \%$ Confidence Interval } \\
\hline & & & & & & & $\begin{array}{l}\text { Lower } \\
\text { Bound }\end{array}$ & $\begin{array}{l}\text { Upper } \\
\text { Bound }\end{array}$ \\
\hline \multirow[t]{3}{*}{ Threshold } & {$[\mathrm{MACOG}=1]$} & -1.815 & .292 & 38.625 & 1 & .000 & -2.388 & -1.243 \\
\hline & {$[\mathrm{MACOG}=2]$} & -.462 & .284 & 2.646 & 1 & .104 & -1.018 & .095 \\
\hline & {$[\mathrm{MACOG}=3]$} & .612 & .284 & 4.636 & 1 & .031 & .055 & 1.169 \\
\hline \multirow[t]{6}{*}{ Location } & Age & .000 & .007 & .001 & 1 & .970 & -.014 & .013 \\
\hline & [year $\exp =1]$ & -.055 & .175 & .099 & 1 & .753 & -.399 & .289 \\
\hline & [year $\exp =2$ ] & -.081 & .164 & .241 & 1 & .624 & -.402 & .241 \\
\hline & [year exp=3] & $0^{\mathrm{a}}$ & & & 0 & & & \\
\hline & [association $=1]$ & -.329 & .136 & 5.853 & 1 & .016 & -.595 & -.062 \\
\hline & [association $=2]$ & $0^{\mathrm{a}}$ & . & 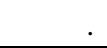 & 0 & . & . & . \\
\hline
\end{tabular}

Source: Researcher's computation via SPSS version-23

\section{Test of Hypotheses}

i. The effect of financial accounting information system services on auditor's independence, professional integrity and objectivity in Abia State, South East Nigeria is not significant.

Table 5: Test of Parallel Lines Ordinal Logistic Regression Effect of Financial Accounting Information System Services on Auditor's Independence Professional Integrity and Objectivity.

\begin{tabular}{lcccc}
\hline Model & -2 Log Likelihood & Chi-Square & df & Sig. \\
\hline Null Hypothesis & 915.412 & & & \\
General & 905.482 & 9.930 & 8 & .270 \\
\hline
\end{tabular}

Source: Researcher's computation via SPSS version-23

Table 5 shows one of the assumptions underlying ordered logistic (and ordered probit) regression is that the relationship between each pair of outcome groups is the same. In other words, ordered logistic regression assumes that the coefficients that describe the relationship between, say, the lowest versus all higher categories of the response variable are the same as those that describe the relationship between the next lowest category and all higher categories, etc. This is called the proportional odds assumption or the parallel regression assumption. Because the relationship between all pairs of groups is the same, there is only one set of coefficients (only one model). If this was not the case, we would need different models to describe the relationship between each pair of outcome groups. We need to test the proportional odds assumption, and we can use the test of parallel lines. The null hypothesis of this chi-square test is that there is no difference in the coefficients between models, so we hope to get a non-significant result [Chi-square $\left.\left(\mathrm{X}^{2}\right)(8)=9.930, \mathrm{p}=.270\right]$. The above test indicates that we have not violated the proportional odds assumption. If the proportional odds assumption was violated, we may want to go with multinomial logistic regression. 
Journal DOI: www.doi.org/10.46654/RJMP

Article DOI: www.doi.org/10.46654/RJMP.1432

Table 6: Plum - Cumulative Odds Ordinal Logistic Regression with Proportional Odds Effect of Financial Accounting Information System Services on Auditor's Independence Professional Integrity and Objectivity.

\begin{tabular}{ccccccc}
\hline Var2 & Wald & Df & Sig & Exp_B & Lower & Upper \\
\hline FAIS $=1$ & 16.625 & 1 & 0.000 & 0.310 & 0.177 & 0.545 \\
FAIS $=3$ & 22.417 & 1 & 0.000 & 3.897 & 2.219 & 6.844 \\
Year-Exp & 0.861 & 1 & 0.353 & 1.164 & 0.845 & 1.604 \\
Association & 1.098 & 1 & 0.295 & 1.152 & 0.884 & 1.502 \\
\hline
\end{tabular}

Source: Researcher's computation via SPSS version-23

Table 6 shows the cumulative odds ordinal logistic regression with proportional odds effect of financial accounting information system services, years of experience and professional association on auditor's professional integrity and objectivity. An increase in years of experience (expressed in years) was associated with an increase in the odds of considering financial accounting information system services as one the factors influencing auditor's independence, with an odds ratio of 1.164 (95\% CI, 0.845 to 1.604$)$, Wald $\chi^{2}(1)=$ $0.861, \mathrm{p}=.353$. While the odds of ANAN considering financial accounting information system services effect too high was $1.152(95 \% \mathrm{CI}, 0.884$ to 1.502$)$ times that of ICAN, a non-significant effect, Wald $\chi^{2}(1)=1.098, \mathrm{p}=.295$.

Table 7: Model Fitting Information of Ordinal Logistic Regression Effect of Financial Accounting Information System Services on Auditor's Independence Professional Integrity and Objectivity.

\begin{tabular}{lcrcr}
\hline Model & $\mathbf{- 2}$ Log Likelihood & Chi-Square & df & \multicolumn{1}{c}{ Sig. } \\
\hline Intercept Only & 917.630 & & & \\
Final & 915.412 & 2.217 & 4 & .696 \\
\hline
\end{tabular}

Source: Researcher's computation via SPSS version-23

Table 7 indicates that the model predictors did not explain the variability in response/outcome variables (rating) adequately. Based on this analysis we accept the null hypothesis $\left(\mathbf{H}_{0}\right)$ and reject the alternate hypothesis $\left(\mathbf{H}_{\mathrm{a}}\right)$ and can conclude that the effect of financial accounting information system services on auditor's professional integrity and objectivity in South East Nigeria is not significant [Chi-square $\left(\mathrm{X}^{2}\right)(4)=2.217, \mathrm{p}=.696$ ]. ii. The effect of Treasury Advisory Services on Auditor's Professional Competence, Skepticism and Behaviour in Abia State South East Nigeria is not statistically significant.

Table 8: Test of Parallel Lines Ordinal Logistic Regression with Proportional Odds Effect of Treasury Advisory Service on Auditor's Professional Competence, Skepticism and Behaviour.

\begin{tabular}{lcccc}
\hline \multicolumn{1}{c}{ Model } & -2 Log Likelihood & Chi-Square & df & Sig. \\
\hline Null Hypothesis & 923.204 & & & \\
General & 915.294 & 7.910 & 8 & .442 \\
\hline
\end{tabular}

Source: Researcher's computation via SPSS version-23

Table 8 shows one of the assumptions underlying ordered logistic (and ordered probit) regression is that the relationship between each pair of outcome groups is the same. In other words, ordered logistic regression assumes that the coefficients that describe the relationship between, say, the lowest versus all higher categories of the response variable are the same as 
those that describe the relationship between the next lowest category and all higher categories, etc. The null hypothesis of this chi-square test is that there is no difference in the coefficients between models, so we hope to get a non-significant result [Chi-square $\left(\mathrm{X}^{2}\right)(8)=$ $7.910, p=.442]$. The above test indicates that we have not violated the proportional odds assumption.

Table 9: Plum - Cumulative Odds Ordinal Logistic Regression with Proportional Odds Effect of Treasury Advisory Services on Auditor's Professional Competence, Skepticism and Behaviour.

\begin{tabular}{ccccccc}
\hline Var2 & Wald & Df & Sig & Exp_B & Lower & Upper \\
\hline VAS $=1$ & 25.499 & 1 & 0.000 & 0.233 & 0.132 & 0.410 \\
VAS $=3$ & 15.087 & 1 & 0.000 & 3.038 & 1.734 & 5.323 \\
Age & 0.052 & 1 & 0.820 & 1.002 & 0.988 & 1.015 \\
Year-Exp & 0.590 & 1 & 0.442 & 0.874 & 0.620 & 1.232 \\
\hline
\end{tabular}

Source: Researcher's computation via SPSS version-23

Table 9 shows the cumulative odds ordinal logistic regression with proportional odds effect of treasury advisory services, age and years of experience on auditor's professional competence, skepticism and behaviour. Millar (1985); Corless and Parker (1987) Wines (1994) Kinney et al (2004) Ashbough et al (2003) did not find systematic in age (expressed in years) was associated with an increase in the odds of considering treasury advisory services as factors influencing auditor's professional competence, skepticism and behaviour, with an odds ratio of $1.002(95 \% \mathrm{CI}, 0.988$ to 1.015$)$, Wald $\chi^{2}(1)=0.052, \mathrm{p}=.820$.

The effect of Treasury Advisory Services on Auditor's Professional Competence, Skepticism and Behaviour in Abia State is not statistically significant. From the result of the findings, it is believed that rendering treasury advisory services does not affect auditor's professional competence, skepticism and behaviour. For this is in line with Glezen evidence showing that auditors violate their independence as a result of client purchasing relatively more non audit service. Also in line with Frankel et al (2002) several studies have reexamined the negative effects of NAS on audit quality and found in his study that NAS has no effect on auditor's independence and behaviour. There are also studies that indicated that tax consultancy might boost the quality of the audits (Kinney jr, Palmrose \& Scholz, 2004). This argument was grounded on the idea that offering non-audit service permits auditors better understanding their clients, resulting in an enhancement in the financial audit (Simunic, 1984).

\section{For hypothesis Three}

The effect of Independent Assurance Work and corporate governance services on auditors' independence and professional judgment in South East Nigeria is not significant.

\section{Conclusion and Recommendations}

The major findings which have crystallized from this study include the following;

That the effect of financial accounting information system services on Auditors professional integrity and objectivity in Abia state is not significant. That the effect of Non -audit services on Auditors independence, professional skepticism and objectivity is not significant. That allowing auditors render Non -audit services strengthens their confidence and provides 
competitive advantage.

In the light of the observations made, the following recommendations are made:

1. External auditors should brace up to the challenge of the auditing profession by imbibing the culture of integrity and accuracy to save the dwindling image of the profession. In this regards, the Institute of Chartered Accountants of Nigeria (ICAN), the umbrella body responsible for regulating auditing practice in the country should put stringent measures to check the excesses of its members to adhere strictly to its code of conduct.

2. The audit committee should have full oversight of the auditors independence, including the nature and extent of the work they do and their fees.

3. The audit committee should make its charter public. The charter should give investors information about how the audit committee chooses its auditors and how it decides what type of service they can provide. 


\section{REFERENCES}

Adeyemi \& Okpala(2011) The impact of audit independence on financial reporting; Evidence from Nigeria.

AICPA, (1988).Code of Professional Conduct: Rule 100, American Institute of Certified Public Accountants. [Online] Available: www.aicpa.org.

Akeloy \& George (1970) The Market for lemons quality uncertainty and the market mechanism quarterly, journal of economics vol. 84 No. 3 (Aug 1970) 488-500 stale URL.

Al-Ajmi,S.Saudagaran(2011) .Perceptions of auditors and financial statement users regarding Auditors independence in Bahrain/ semantic scholar, www semanticsscholar.org.paper.

Anichebe A. (2010) Auditor in independence and the provision of non audit service in Nigeria . European journal of Accounting Auditing and finance research vol3, no5.pp108-119, May 2015.

Appah E (2008) Auditors independence: A real issue, creativity science study, 3:66

Awa F. N (2015), Auditors Independence and the provision of non-audit service investors perceptive in Nigeria. European journal of accounting and auditing and finance research vol 3 N0. 5 pp $108-119$.

Beattie, V. Fearnley and Brandt, R. (1999). Perception of Auditor independence: UK Evidence. Journal of International Accounting, Auditing and Taxation, Vol. 8, No.1, pp. 67-107.

Brandon, D., Crabtree, A., and Maker, J. (2004) Non-Audit fees, Auditors Independence and Bond Rating Auditing: A Journal of Theory and practice Vol. 23, N0 2, Pp. 89103.

Chow (1982) The demand for external authority. Size, debt and ownership influences' the accounting review, p 272.

Citron, D, (2003). The UK's Framework Approach to Auditor Independence and The Commercialization of The Accounting Profession, Accounting. Auditing and Accountability Journal, Vol. 16, No. 2, pp. 244-272.

Citron, D. (2003) The UK's framework Approach to Auditor Independence and the commercialization of the Accounting profession accounting, auditing and accountability journal, vol. 16, N0 2, pp. 244-272.

Collins \& Skerralt L., (2004) The Demand for the Audit in a small companies in UK Accounting and business research 34 (2) P. 87-100.

Corless J.C and Parker L.M (1987) the impact of MAS on auditor independence: an experiment accounting Horizon no 1 pp. 25

Cullinane L. (2004), Eron as a symptom of audit process Breakdown: can Sarbanes - Oxley Act cure the disease, critical perspectives on accounting vol. 15, N0. 617, pp 853864.

De Angelo, L.E, (1981). Auditor Independence, LOW Balling, and Disclosures Regulation, Journal of Accounting and Economics, Vol. 3, pp. 183-199. 
Elifsen (2016), The Role of Audit firms size, Non-Audit Services, knowledge Spillovers in Mitigating Earnings Management during Large Equity issues. International Journal of Auditing Vol. 20 Issue 3 pages 239-254.

Ellifsen M. G. Mecking, W. H (1976), Theory of the firm: Managerial Behaviour Agency cost and ownership structure. Journal of financial economic 3(4), 305-360.

Elliott, R.K. and Jacabson, P. (1992). Audit independence: Concept and Application. The CPA journal, Vol. 62, No. 3, pp. 34-39.

Frankel et al (2002) the relation between auditors; fees for non audit services and earnings quality, the accounting review vol. 77

Glezen \& Milliar (1985) an empirical investigation of stock holder reaction to disclosures required by ask no. 250, journal of accounting research, vol. 23, Autumn, pp. 859

Gul (1991) Size of audit fees and perceptions of auditors to resists managerial pressure in conflict situation: Abacus, vol. 27 no 22. Pp 162.

Healy, P. (2003), The fall of Enron Journal of Accounting Research supplement 107-115.

Holland Lane (2012)perceived auditor independence and Audit firm fees .www researchgate. Net.>publication $>1$.

IFAC (2007) IFAC code of Ethics for Professional Accountants, International Federation of Accountants.

Independence Standard Board (ISB) (2000). Exposure Draft (EdOO-2), Statement of Independence Concepts: A Conceptual Framework for Auditor Independence, New York, NY.

ISB Independence Standard Board (2000) Exposure Draft (Ed 00-2) Statement of Independence Concepts; A Conceptual Framework for Auditors Independence New York NY.

Jensen \& Meckling (1976), Theory of the firm managerial behavior, agency cost and ownership structure, journal of financial economic vol. 3, pp 305

Kinney et al (2004) "Auditor Independence non audit service and statement was the U.S Government right journal of accounting research 42(3): 561

Ojo M. (2009) Non audit service and auditors independence investors perceptive in Nigeria. Business and management review vol 12 (5) pp 89-97.

Okaro S. C. and Okafor G. O. (2014) Joint provision of audit and non audit service on Nigeria: An empirical study; the IUP Journal of Accounting Research and Audit practices vol. Xiii, N0. V pp.30-45.

Okaro S.C, Okafor G.O And Egbunike C .F.(2014) Joint provision of audit and non audit service on Nigeria:An empirical study; the IUP Journal of Accounting Research and Audit practices volXiii, NO.V pp.30-45.

Olusanya J. O. \& S. Lauwo (2010), The role of auditors in the Nigeria Banking crisis. Accountancy Business and Public Interest vol 9 p. 159.

Osisioma, H.E. (2004).Conflict Management in Nigeria; a PhD Thesis

Ross (1973) The Economic theory of agency: principles, American Economic Review 62(2); 134 
Salehi (2009) in the name of independence: with regard to practicing Non-audit services in Malaysia international Business Research vol. 2 Vol. (2) pp. 139-147.

Semiu B. A and Johnson K. O. (2012) Non audit services and auditors independence investors perspective in Nigeria. Business and management review vol 2 (5) pp 89-97.

Semiu B.A and Kehinde O.A (2011) Stakeholders perception of the independence of statutory auditors in Nigeria. Serbian journal of management 6(2) 2011 pp 247267.

Uchenna N. A (2004) Determinants of auditors independence a comparison of the perception of auditors and non-auditors in Lagos Nigeria. Journal of Finance and Accountancy p. 1-5.

Ukpebor I. Enofe A. Ogbomo N. (2015), The effect of accounting ethics in improving auditor professional skepticism. International journal of advance of academic research vol 1 , issue 2 .

Watts and Zimmeman (1983) Agency problems, Auditing and Theory of the firm journal of Law and Economics. Vol. 26, No. 3 (Oct 1983).

Wines (1994) Auditors Independence audit qualifications and provision of non audit services: a note accounting and finance, vol. 34, pp 75 


\section{Effect of Non-Audit Service on Auditor's Independence Questionnaire (ENSAIQ)}

Instruction: The ENSAIQ is divided into two sections. Sections A captures bio-data of the respondents while section B seeks data regarding the variables. Please tick $(\sqrt{ })$ the appropriate level of agreement as applicable to each statement. The statements are rated 4-point Likert-scale type and with their respective points: Strongly agreed-SA(4), Agree-A(3), Disagree-D(2) and Strongly agreed-SD(1) below:

\section{SECTION-A}

\section{Please, tick $(\sqrt{ })$ as appropriate:}

Association:

\begin{tabular}{l}
\begin{tabular}{|l|l|l|l|l|}
\hline \multicolumn{3}{|c|}{ ANAN } & \multicolumn{5}{|c|}{ ICAN } & \\
\hline Age: & & & \\
\hline
\end{tabular} \\
\hline
\end{tabular}

Years of Experience as Auditor:

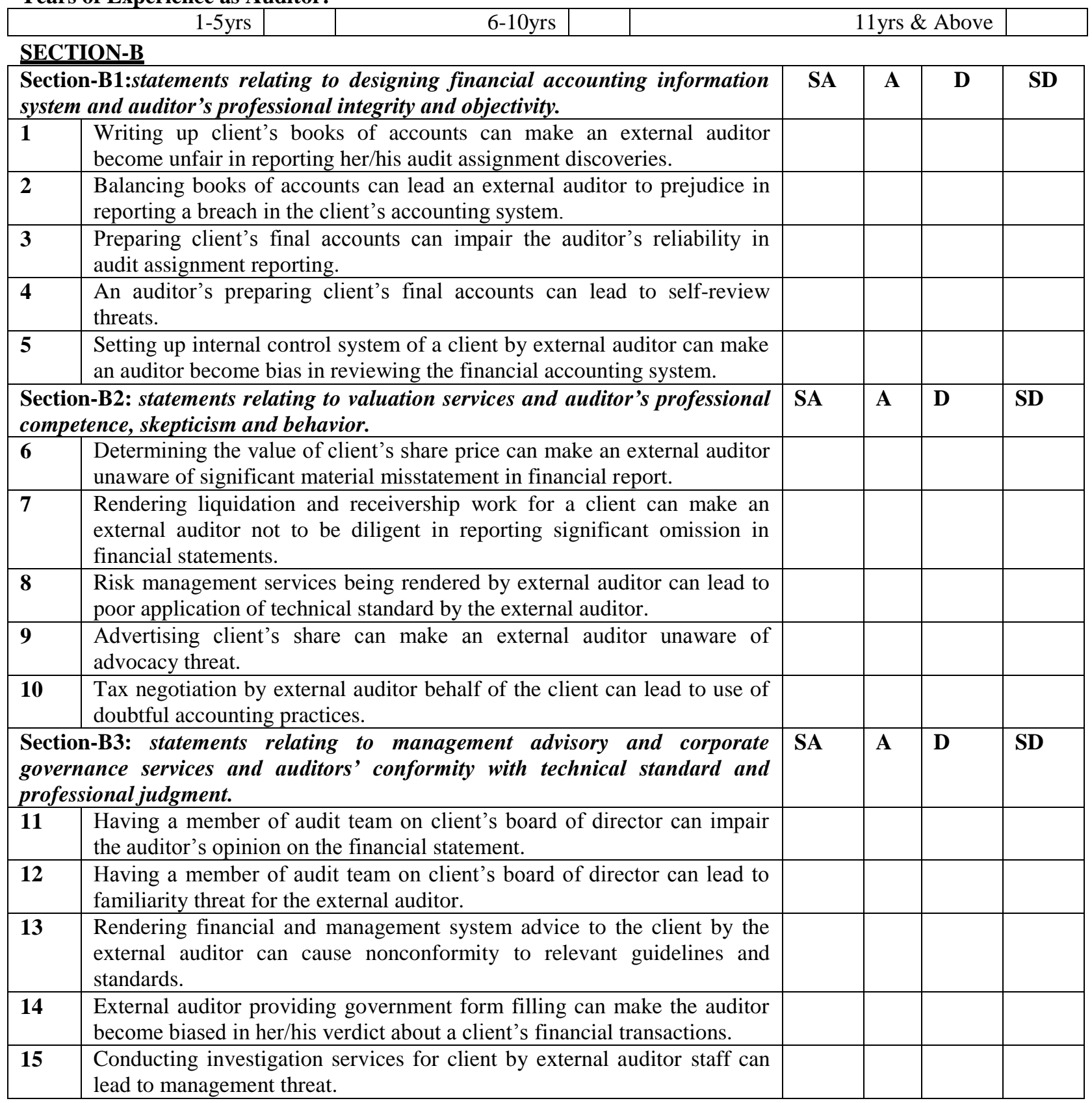

